\title{
Hvem var Clara?
}

\author{
AfKaj Thaning
}

Med tak til Dr. Oscar Wood, Christ Church College, Oxford.

\section{Clara og Disraeli}

I min disputats "Menneske først - Grundtvigs opgør med sig selv “ (1963) gik jeg ind for den tanke, at Grundtvigs møde med Mrs. Bolton d. 24.6.1830 hos juristen Mr. Heaton bevirkede en ændring af hans livssyn, og at hun blev hans muse gennem en længere årrække. Påstanden mødte både tilslutning og skepsis, men bortset herfra er det naturligt at spørge, hvem denne Mrs. Bolton egentlig var, som Grundtvig vitterligt blev stærkt betaget af. Ja, han skriver $i$ et (uafsendt) brev til værten Mr. Heaton: "... siden jeg kom til Skiels Aar og Alder, og det er temmelig længe siden, saa er jeg ikke blevet saa betaget, for ikke at sige mere, af nogen Dame i Verden" (J.P. Bang: Grundtvig og England s. 70).

Grundtvig fortæller om sit møde med hende (i et brev til Lise derhjemme): "Rimeligvis besidder hun hvad man her kalder en stor uafhængig Formue, som jeg slutter af den Frihed, hvormed hun behandlede hele Selskabet, og den Udmærkelse Alle viste hende. Hun nævnede mig iblandt Andet flere litteraire Mænd, som hendes gode Bekiendtere, og jeg formoder, hun vil indføre mig hos dem, da hun ved Afskeden lod Mr. Heaton sige mig og stadfæstede derpå selv, at hun håbede og ønskede, jeg vilde giøre hende et Besøg, hvortil jeg fik hendes Addresse og seer, hun boer i den allerfornemste Deel af Vest-Enden «. Først efter samværet blev han klar over, at hun var gift, og at han ikke havde hilst på hendes mand, og over for sin kone angav han det som grund til, at han ikke senere havde besøgt hende: "... naar jeg havde været $i$ Selskab med en Fremmed og ei værdiget ham mindste Opmærksomhed, da vilde jeg mene at have frabedt mig hans Besøg ..." .

Forud for dette citat hedder det: "De Personer, jeg havde mest 
at giøre med var ellers den svenske Legations-Secretair Baron Roland, som var min Sidemand ved Bordet, og en ung Dame (jeg ved ikke om Jomfru eller Enke) Mrs. Bolton, som, efter Bordet, gav sig i Snak med mig, og er den interessanteste Dame, jeg endnu har seet. "Selskabet var ikke stort, men behageligt og til dels fornemt - "der blev tracteret og moret på det bedste", og først ved 1-tiden tog han af sted (»Englandsbreve s. 97-100). Men hvem var Mrs. Bolton?

- En af mine døtre var i 1956 i huset hos Dr. Oscar Wood, Christ Church College i Oxford, som hun forelagde det spørgsmål, om det var muligt at finde frem til damen. Han forkastede med rette det forslag, som udgiverne af Grundtvigs Englandsbreve (s. 194) har fremsat, at der skulle være tale om Maria Bolton, ældste datter af Lord Guy Dorchester, 1810 gift med baron William Orde-Powlett Bolton til Bolton Castle (York). Dels var hun alt for gammel til Grundtvigs beskrivelse "en ung dame", dels ville han have omtalt hende som "Lady Bolton". Der måtte være tale om en anden.

Under korrekturlæsningen på disputatsen modtog jeg besked fra Dr. Wood: nu var hun funden! En ven af ham, Robert Blake, var ved at skrive en Disraelibiografi og havde i Disraeliarkivet $i$ Hughenden Manor, Disraelis ejendom, fundet et bundt breve, deriblandt ca. 15 fra en Clara Bolton. I et af dem omtaltes en mand, som jeg havde opgivet Wood som en af dem, Grundtvig havde været sammen med d. 24.6.1830: "den svenske Legationssecretair Baron Roland ". Det svenske Riksarkiv bekræftede 17.9.1963, at den svenske legationssekretær i London fra 1822 til 1833 var friherre Åke Vilhelm Rålamb. Grundtvig har hørt forkert. Men hans Clara var altså fundet - og hed netop Clara, jfr. hans digt til Claras pris i "Danskeren" 1848. Her siger hun om sin samtale med Grundtvig, da værten spørger, hvad de dog kan have at tale om (værten Mr. Heaton var nævnt i samme brev som baron Rålamb): "... den Ting er ikke $\mathrm{i}$ Verden til, hvorom vi to jo kan tale sammen!«

Dr. Wood rejste til Hughenden Manor nogle dage, og til mig kopierede han 13 breve fra Clara Bolton og et fra Disraelis søster Sarah til broderen - et meget vigtigt brev. Disse breve giver et indtryk af Clara Bolton i en periode af hendes liv. Den første af Disraelibiograferne, der har udnyttet dem, var den amerikanske 
professor B. R. Jerman i "The Young Disraeli " (1960). Papirerne i Disraeliarkivet var da frigivet. Derefter brugte Robert Blake dem ("Disraeli“ 1963) og nu sidst Sarah Bradford ("Disraeli" 1983).

Det var Disraelis forretningsfører gennem mange år Sir Philip Rose, der efter hans død ordnede de efterladte papirer. Sammen med brevene fra Clara Bolton findes en tyk stabel breve fra Lady Henrietta Sykes. Hun var i årene 1833-36 kendt som Disraelis elskerinde, og forbindelsen med hende var nær blevet skæbnesvanger for hans politiske karriere. Det hedder sig (iflg. Philip Rose), at Robert Peel af denne grund undlod at gøre Disraeli til minister i 1841.

I anledning af Clara Boltons breve siger Rose, at hun - også blandt medlemmer af Disraelis familie - blev anset for at være Disraelis elskerinde. Det gengives af alle de næunte Disraelibiografer. Blake mener, at det er Benjamins yngre brødre, det rygte stammer fra - Rose var en jævnaldrende syttenårig nabo til familien. Det er givet, at Clara Bolton har været stærkt betaget af Disraeli, hans fremtræden, hans begavelse, hans forfatterskab og ikke mindst hans veltalenhed under valgkampen i 1832, da han to gange stillede op ved parlamentsvalget i High Wycombe. Men intet $\mathrm{i}$ hendes breve tyder på en stærk forelskelse. Man kan sammenligne med Henrietta Sykes' breve. De formelig gløder af elskov (jfr. Blake om Clara Boltons breve s. 75: "There is not the unequivocal eroticism that one finds in the letters from H. S. ").

Alle ved, at Clara korresponderer med Disraeli. I slutningen af et brev skriver hun, at hendes mand (lægen George Buckley Bolton) utålmodigt venter på, at hun skal blive færdig, så han kan tage brevet med. Hun sender altid hilsener til familien, specielt søsteren Sarah. Et andet brev får broderen Ralph med til Bradenham, familiens ejendom - han har hurtigt kunnet spinde en ende over korrespondancen og betroet sig til Philip Rose! Andre sender også besked med til Disraeli, bl.a. hendes ven Angerstein, som hun gerne vil have gift med Sarah.

Disraeli ønsker hun også gift, men »ikke med hvemsomhelst". Der er fremsat nogle forslag over for ham, men dem vil hun ikke acceptere - de damer vil kede ham til døde. Nej, "you must have a brillant star like your own self. Keep your heart quiet! " Men hun har selv et forslag, en veninde ved navn Marga- 
ret Trotter, der bor på et landsted uden for London. Clara vil snart besøge hende og inviterer Disraeli derud, og så kan de alle tre besøge en smuk park $\mathrm{i}$ nærheden: "Jeg ved, at når du ser hende, vil du føle dig inspireret til at skrive og gøre hende til din heltinde". Han skriver nemlig den ene roman efter den anden, mens han besøger sin familie. I det sidste brev til ham (19.11.1832) hedder det: "Intet kunne forsone mig mere med denne onde verden end at se hende som din hustru«. Havde Clara været hans elskerinde, ville hun vel ikke have ønsket ham i armene på sin bedste veninde!? (for resten ved jeg ikke, om hendes "you " skal oversættes ved du eller De!).

- Brevene er nummererede, men ikke i kronologisk orden. De falder i tre grupper. Den midterste og største er fra valgkampen i juni 1832. Der er så nogle få af tidligere dato (kun det sidste brev er dateret) og nogle få fra efteråret. Jeg har forsøgsvis prøvet at finde rækkefølgen: gruppe 1 skulle da bestå af numrene 13, 11 og måske 12. Gruppe 2 af 7, 4, 1, 3, 2, 6, og 5. Og gruppe tre af 9, 8 og 10. De er alle sendt til Bradenham, der ligger i valgkredsen, "the rotten borough" High Wycombe. Det sidste af dem er sendt fra en anden adresse end den sædvanlige, 3 King Street, St. James - nemlig 21 Alexander Square (Jerman skriver fejlagtig nr. $2 \mathrm{og}$ angiver derfor antagelig en forkert ejer af huset). Ganske vist går ægteparret Bolton fra hinanden, men ikke endnu. Intet $\mathrm{i}$ brevet tyder på, at der er sket en ændring i Clara Boltons forhold. Det eneste, man kunne pege på, er, at hun slutter brevet med at erklære, at "middagen blev en fiasko "! Det er noget helt nyt, for hendes gilder plejer at være vellykkede. Men det kan jo være, at middagen ikke har været hos hende selv!

Der sker en vis ændring i brevenes tiltaleform og vel dermed også i forholdet imellem korrespondenterne. De tre første begynder: "My dear Sir". Derefter er der nogle, der blot har "B. Disraeli Esqre". Under valgkampen og derefter lyder det mere personligt "My dear Disraeli ". Brevafslutningerne veksler helt tilfældigt mellem "yours very faithful", "your most faithful", "ever yours very faithful", "yours sincerely" og "yours very truly".

Familierne Bolton og Disraeli har kendt hinanden fra midten af tyverne, fra dengang de boede i samme by, og Disraelierne har åbenbart haft Bolton til læge. Lige før Benjamin Disraeli tog på 
en lang rejse til Østen - i 1830 - har George og Clara Bolton opholdt sig nogen tid i Disraeliernes nye hjem Bradenham, fordi Benjamin var syg. Doktorens behandling gjorde ham dog ikke synderlig meget bedre. Af denne grund lærte Clara Bolton familien at kende og sender stadig hilsener til den. Under valgkampen beder Disraeli sin søster invitere hende til Bradenham med den begrundelse, at hun kunne være ham til stor nytte, men er åbenbart ikke sikker på, at Sarah er villig til det. Hun har været meget forbeholden over for Clara Bolton. Men hendes grund kan ikke være den, at hendes bror har et intimt forhold til hende, for hun tog selv på et senere tidspunkt initiativet til at invitere hans elskerinde Lady Sykes, skønt hun frygtede for, at den fine dame skulle kede sig frygteligt i Bradenham, hvor man levede under ganske borgerlige forhold. Hun har været imponeret af broderens erobring og har været helt solidarisk med ham $i$ hans kamp for at nå frem.

Det er muligt, at brevvekslingen mellem C. B. og Disraeli begynder med et brev, hun skriver til ham for at bede om hans hjælp i anledning af, at en af hendes venner, en præst ved navn Alexander d'Arblay søger en stilling ved et hittebørnshospital (Blake s. 76). Hun håber, at hans far har forbindelser, der kan hjælpe til. I det brev, jeg regner for det første af dem, jeg har, hentyder hun nemlig til en personliste, hun har sendt med henblik på ansøgningen til hospitalet. og hun tilføjer, at "næste gang" han kommer til byen, skal han fă d'Arblay at se. Disraeli har åbenbart besøgt hende.

Men han har udtrykt ønske om, at hun vil skrive til ham: "You are too kind to wish me to write". Han har altså sat korrespondancen i gang med anledning $\mathrm{i}$ hendes bøn om hjælp. Pudsigt nok begynder hun det første brev med samme vending, som hun slutter det sidste med: "God is great", hans yndlingsudtryk, - en reminiscens fra hans rejser i Østens lande. ${ }^{1}$

I det første brev fortæller hun om en af sine venner Angerstein, for resten en søn af en veninde af forfatterinden Fanny Burney, som vi siden skal komme til. Angerstein bliver holdt meget hårdt af sin rige far, hvad der må kunne trøste Disraeli, som har et lignende forhold til sin far. Men som eksempel på, hvilke egenskaber Clara Bolton sætter pris på, vil jeg citere følgende ord om Angerstein: "I cannot say too much in praise of him, he has such 
a fine generous heart, with the highest principles of honour, without the slightest affectation, and heir to one of the best properties in England ... «. Hun har en bagtanke med at sige det, for Disraeli må endelig sige det til sin søster, "for he is a gem rarely to be picked up ...".

$\mathrm{Ja}$, hun indrømmer, at hendes hovede er en formelig roman, hvor hovedpersonerne er ham selv og Margaret Trotter og så Angerstein "and your darling of a sister". Hun tilføjer, at Angersteins far vil betale al hans gæld, hvis han finder sig en kone! Hun vil åbenbart gerne arrangere.

Med henblik på den valgkamp, der forestår, hvor Disraeli vil stille sig, uafhængig af både whigs og toryer, forbereder hun sig på at blive hans impressario. Hun kender "all the best people", og bl.a. vil hun gøre "Lord Johnny" fortrolig med hans navn, "before he trembles under your lash of eloquence. Attack those Whigs with hurricanes and earthquakes ... « I anledning af betegnelsen "Lord Johnny" beskylder Blake hende for "NameDropping " - at lade, som om man står på fortrolig fod med de betydningsfulde personer, man omtaler på den måde, men det drejer sig om Lord John Russell, den store Whigleder og senere premierminister, som hun virkelig har meget at gøre med. Bl.a. benytter hun sig meget af ham, når hun mangler "a frank ", d.v.s. en kuvert, der befordres frit med posten. Parlamentsmedlemmer havde ret til uddele dem.

Men hun er altså "Lord Johnny«s politiske modstander. Hun kommer sikkert fra torykredse, men samtidig fra et milieu, der er i politisk opbrud. Hun fortæller, at hun om nogle dage skal mødes med bl.a. Mrs. Bulwer, hvis mand digteren Bulwer blev valgt som "radikal " til parlamentet. Han blev Disraelis nærmeste ven, og de var i starten politisk enige. Uafhængigheden var det centrale. Men Disraeli endte jo blandt toryerne, idet hans indsats blev at modernisere partiet. Idealet for ham var, at de gamle jordejere skulle stå sammen med arbejderklassen mod den nye industriadel. Lord Lytton Bulwer, som han siden kom til at hedde, var ligesom Disraeli både digter og politiker. Han var primært det første, Disraeli det sidste.

Clara Bolton færdedes mest i litterære kredse. Hun kom altså hos Bulwer's, og forfatteren Charles Gore var hendes ven, der tit omtales i brevene. Hun inviterer Disraeli til at komme til London 
for at se hans komedie "Lords and Commons", der snart skulle opføres. Hun har gerne en "box" d.v.s. en loge til rådighed $\mathrm{i}$ teatrene, hvortil man kan trække sig tilbage $i$ pauserne for at underholde sig med ligesindede. I anledning af indbydelsen tilføjer hun: "I have a crib at your disposal at all times, we must be economical ...". Dette sted er i Disraelibiografierne blevet fortolket som tegn på det intime forhold mellem de to, men det vil man da kun falde på, når man leder efter sådanne tegn! Der er jo tale om en stående indbydelse til en mand uden penge, der ovenikøbet skal overtales - hun tilføjer: "When I make an offer it is meant".

I et brev under valgkampen tilbyder hun ham også en seng $\mathrm{i}$ King Street, hvis han kommer til et skuespil i London. "The music will inspire you ". Og så tilføjer hun: "I have so much to say I cannot write about ". Heller ikke her behøver man at ane uråd, for hun er fuld af nyt om folks indstilling til valget og deres syn på Disraeli, men hun kan simpelthen ikke nå mere - hun begynder brevet med at oplyse, at hun kun har ti minutter at skrive i, og hun kan ikke få "a frank " af de rasende whigger og må derfor spare på vægten (Disraeli skal betale portoen, der retter sig efter vægten). Af den grund skrives den sidste del af brevet på begge leder (hvad der har voldt Dr. Wood vanskeligheder under kopieringen).

Men tilbage til det første brev, der rummer et eksempel på selskabslivet i London, som hun er ekspert i. Sammen med Mrs. Bulwer, Charles Gore og en dame ved navn Sylvia (uidentificeret) skal hun til et selskab med "spanske lege", og hun beskriver en af dem (som dog også er kendt i Danmark): den spanske ambassadør står i midten af værelset med en guitar, og alle står omkring ham. Han spiller, holder op og sætter sig pludselig ned, og alle skal gøre det samme, men hver gang mangler der en stol, og en må gå ud af legen. Til sidst er der kun een - vinderen tilbage. - Hun tilføjer, at en tilstedeværende russer også vil bidrage til underholdningen. Vi er i et internationalt milieu.

Hun er ikke ukritisk over for livet i London. Hun misunder ham hvilen ved landlivet, men byen har nu sin charme: "I like society in the way I generally take it, I detest large stupid well filled rooms with nothing but well dressed people «. I det næste brev fortæller hun om et gilde, der til hendes overraskelse blev vellykket: "The party of last night was very amusing ". Hun var 
ikke oplagt til at tage afsted, "but the collection of animal curiosities was better than is usually exhibited in a London house room ". Alle mulige nationer var til stede, og man hørte alle sprog, italiensk, spansk, græsk i lystig sang. Nogle få boglærde talte om metafysik og om Letitia E. Landons sidste roman - hun var en i de litterære kredse meget omtalt ekscentrisk dame, med håret sat op á la Sappho (græsk var på mode, jfr. Byrons død i Grækenland). $\mathrm{Nu}$ er hun glemt. Men de nævnte boglærde anså hendes roman for at være vidunderlig, fordi den angik emner ud over deres forstand, moralfilosofi og metafysik - "you know the line this old Jerdan puffs". Jerdan udgav "The Literary Gazette". Ham kender Clara Bolton også og fortæller, at hun engang fik ham til at anmelde "a Latin work of a particular friend of mine without either of us understanding a word. We relied solely upon the ignorance of the public". Men uheldigvis viste det sig at være noget bedrøveligt sludder.

Jeg gengiver dette til belysning af Clara Boltons milieu. Det er litterært og internationalt. Hun har forbindelser med nøglepersoner (old Jerman) - men udleverer altså også sig selv og sin uvidenhed: hun forstod ikke et ord af det lærde værk. Det var ovenikøbet skrevet af en af hendes venner. Ved det samme gilde kom der ret sent en mand, som ingen kunne forstå: han talte "in unknown tongues «! Den frygtelig forvirrede værtinde "appealed in her agony of mind to me, thinking from the many escapes I have had of my life I might be conversant with the dead languages ...". Hun tog da også affære - dog uden at forstå manden. "In order to screen my ignorance I reported him mad, the word went like wild fire ...". Så kom Charles Gore og stirrede ham fuldstændig ud!

Her får vi en del at vide om Clara Bolton. Hun har haft mange "escapes" trods sin ungdom. Det kan betyde, at hun har studeret mange forskellige ting, også gamle sprog. Men det kan jo også betyde, at hun har rejst meget og på sine rejser lært mange sprog. I samme brev fortæller hun om en anden selskabsleg i et meget internationalt selskab, hvor det var nødvendigt at kunne tale flere forskellige sprog. Hun måtte under legen henvende sig til en italiener og benyttede da fire forskellige sprog, så manden blev helt forvirret ved at høre både engelsk, fransk, italiensk og spansk. Ubegavet kan hun ikke have været, og hurtig i vendingen har hun sikkert været. 
I et brev om hende, det eneste af den slags, der kendes, og som senere skal gengives, fortælles det, at hun er meget veltalende, munden går på hende, selv om hun er syg. ${ }^{2}$ I det lige citerede brev giver hun selv et eksempel på, at hun kan snakke en mand fuldstændig ned med sin rivende talestrøm. Men det er jo taktik: hun vil skjule sin uvidenhed! Det morer hun sig med at fortælle Disraeli.

Han har som sagt bedt hende skrive til ham. Men da de åbenbart ikke kender så forfærdelig meget til hinanden, og hun ved, at hun skriver til en meget begavet mand, så afbryder hun sig selv midt $i$ brevet efter at have fortalt løst og fast og siger: "I wonder if I bore you what would I not give to know. I go on without thinking of your nerves or the time and if I could but flatter myself you are not annoyed I should be supremely happy" (tegnsætning ser man stort på i den tids brevskrivning. Jeg har her tilføjet et punktum og gør noget lignende $i$ andre citater).

Dette brev er antagelig det andet, hun skriver til Disraeli på hans opfordring, så det er naturligt, at hun er usikker på, hvilket indtryk hun gør på ham. I slutningen kommer hun tilbage til det spørgsmål, om hun keder ham. "Will you be candid? is that one of your qualities and say if I bore you, for I imagine you must be heartily sick of me, I am an oddity and accustomed only to write as I think, never for effect, but my dear kind creature do tell me if I annoy you - I can get up any style you like, all I want is to hear that you are well and that nice valuable sister of yours the same ....".

Hvad mener hun mon med at skifte stil? Mon ikke skifte emne? Hun vil fortælle noget, der interesserer ham, og ser man på dette brev, så slår hun over fra det ene emne til det andet. Det første punkt er, at d'Arblay gerne vil takke for venlig omtale af ham (jfr. hans ansøgning). Hans mor forfatterinden Fanny Burney er også meget taknemmelig. Hun får en kommentar med på vejen: "What a rare creature she is". Jeg nævner det, fordi vi siden kommer til d'Arblay og hans mor. Måske kender Clara Bolton Fanny Burney gennem hendes søn.

Så fortæller hun om Lord John Russell's og Charles Gore's interesse for Disraeli og hans politiske standpunkt. Men hun advarer ham mod whiggen John Russell: "Look upon him as a curse to this country". Lidenskabelig er hun. Hun fortæller om 
kongens trussel over for parlamentet om at opløse det og desuden tage valgretten fra "the boroughs" (altså også High Wycombe), hvis "the Bill" ikke bliver vedtaget, og hun kommenterer dristigt: "What a scamp»! Hun fortsætter om kongen: "He roared out his speech and terrified the Commons, went to the House without even a cheer, I had the felicity of witnessing his silent return". - Hun giver virkelig Disreali et førstehånds indtryk af begivenhederne - og er lige ved selv at være en historisk kilde!

Så følger en beretning om en meget mystisk person Baron de Haber, som var af tysk og jødisk afstamning, en finansmand med hovedsæde i Haag. "My consistent friend", kalder C. B. ham, og det er muligt, at det er hende, der har sat ham $i$ forbindelse med Disraeli, hvad der skulle blive meget uheldigt for denne. Økonomisk kom han i uføre ved samarbejdet med Haber og politisk på gale veje, da Haber i Frankrig tilhørte en antirevolutionær bevægelse, der stilede mod at få den fordrevne Karl d. X (af Frankrig) tilbage på tronen. Det medførte konflikt med den engelske regerings politik. Det vides ikke, hvordan C. B. havde fået forbindelse med ham. I det her citerede brev refererer hun hans voldsomme planer om snigmord på både The Times og Macaulay! Man mærker på tonen, at hun nok anser ham for en fantast, men baronen figurerer altså som medlem af den kreds af Lorder, baroner, diplomater og forfattere, som hun står på mer eller mindre fortrolig fod med. Disraeli har truffet dem hos hende, og derfor fortæller hun om dem i brevene. Eller hun ønsker, at de skal lære ham at kende. Hun slutter omtalen af Haber med at referere, at han vil vædde på, at inden fire måneder vil vi have "a glorious revolution «! Hun tager ham ikke alvorligt.

Så er det, hun spørger Disraeli, om hun keder ham, hvorefter hun beretter om de fester, hun har deltaget $i$, med en omhyggelig beskrivelse af de selskabslege, hun der har været med til. Men igen slår så "stilen" om, idet hun på grund af et forestående besøg på landet hos veninden Margaret Trotter fordyber sig i forholdet mellem land og by. "I am so devoted to drawing those green fields and shady lanes, smiling brooks, you know what else, in fact all the requisites of a landscape". Man ser hende sidde, denne moderne bydame, og tegne alle de "rekvisitter", der hører til det romantiske landskab. Uden tvivl typisk for Londons society. 
Men hun fortsætter: "I no sooner begin to be serious than I am interrupted " - det er en veninde, der ringer på for at fortælle en lang melankolsk historie om et ulykkestilfælde. Hun må fælde tårer over det. Nu var hun lige begyndt at blive alvorlig - og så afbrydes hun af sentimentaliteten. Jo, der er stilskift $i$ hendes brev. men hvad morer og hvad keder ham? Der er en modsætning mellem hendes erklæring om, at hun kan skifte stil efter hans ønske - og så påstanden om, at hun er vant til at skrive, som hun tænker, "never for effect ". Det sidste ligner hende uden tvivl bedst. Det første røber usikkerheden over for forfatteren Disraeli, som hun beundrer, og som har bedt hende skrive til ham. Til gengæld slutter hun brevet sådan: "Whenever you can spare an hour do think of me and write me your thoughts upon affairs in general. I have made my servant man furious waiting for this". Det er ikke nemt at skrive under sådan et pres! Derfor står der efter underskriften: "No time to read my own nonsense Hope all words are proper placed «. - Dette brev giver uden tvivl et ganske godt billede af, hvem Clara Bolton er - i den forste fase af hendes forhold til Disraeli.

Den næste gruppe breve er skrevet under valgkampen, og Clara har overvundet sin ængstelse for at kede Disraeli, for hvis valg hun nu er gået ind med fuld musik. Hans politiske farver er lyserødt og hvidt, og hun syr af al kraft blomster i de farver, som hans tilhængere kan pynte sig med. Hendes venner fortæller hende, at "they never saw me take so much trouble about anything as your election «. I det første af disse breve skriver hun mod slutningen: "If I can be of any use command me". Hun refererer alt hvad hun hører fra sine venner om stemningen for eller imod Disraeli og formaner ham til ikke at røbe noget af det, for at hendes kilder ikke skal tilstoppes. Hun fortæller om den fiasko, hans modstander whiggen oberst Grey har haft med sin valgtale, og om den begejstring, Disraeli har vakt med sin. Kun indirekte får man indtryk af hendes eget politiske syn, når hun f.eks. hader at høre ham omtalt som radikal, og når hun lægger luft mellem ham og whiggerne, som hun opfordrer ham til at gøre det af med.

Under valgkampen får man en ny side af hende at se, idet det viser sig, at hun er en veninde af Eliza Flower, som styrede hus for unitarpræsten William Johnson Fox. Han var en kendt skik- 
kelse både i det politiske og det litterære milieu. Disraeli kendte ham og sagde om ham: "He is a capital fellow, and likes my novels ". Det kunne Disraeli aldrig stå for (Jerman s. 168, noten).

Fox var skilt og hans beundrer Eliza Flower var i hans hus værtinde for en litterær kreds, deriblandt Robert Browning. Clara fik jævnlig besøg af Eliza og også af hendes søster Sarah, der siden blev gift Adams. Hun findes i Den danske Salmebogs forfatterregister. Det var hende, der skrev "Nærmere, Gud, til dig ", en salme, der meget vel kan siges at høre hjemme i det unitariske milieu. Grundtvig snusede til det i London, idet han med en ven, der hørte til "den socinianske kirke», travede den halve by igennem "for at høre en mådelig Clausensk prædiken af en Mr. Fox" (Brev til Lise 3.6.1830).

Clara har åbenbart højst forskellige kontakter. Fox er på Disraelis side og kender en mængde kvækere, som hun selv er skeptisk overfor, men som hun mener vil kunne vindes for Disraeli, så Fox må endelig opsøge nogle "influential men of the tribe "! Men det er bedst, at han som unitar ikke officielt giver sin mening til kende. Hun er strateg. Om kvækerne siger hun: "Those quakers speculate upon going straight to Heaven thro'the colour of their coat and the make of their hats ". Men deres stemmer er jo lige så gode som andres! Hun siger selv: "I am setting everybody to work right and left ".

Brevet handler dog ikke blot om valgkampen. Hun tilføjer, at hun skal have en snes mennesker til soiré om aftenen - og her er det, hun bl.a. nævner Baron Rålamb og Grundtvigs vært Ellis Heaton foruden d'Arblay, baron Haber, Charles Gore og andre, åbenbart hendes nærmeste omgangskreds: "... a regular mob. We are, as you know, not a formal set and do not sit in rows, and I never amuse people give them nothing to do nothing to eat and yet they will come but we are all of the same mind about those things ...". Det er en sådan kreds, Grundtvig har været sammen med hos Heatons, og hvor han har befundet sig vel.

Hun kender, som før nævnt, selskabslivet i London fra en anden side, og der findes da også rædselsvækkende skildringer af de store, stive selskaber på den tid med professionel underholdning og uden mulighed for virkelig personlig kontakt. Omkring Clara Bolton har man moret sig, og hun har sikkert selv været en glimrende værtinde. Gennem Grundtvigs skildring får man også 
indtryk af, at hun har været det naturlige midtpunkt hos Heatons.

Der er noget hæsblæsende over hendes breve fra valgkampen. Hun skriver under stort tidspres, og associationerne yngler. men ind imellem giver hun Disraeli besked om muligheden for at leje heste - til væddeløb (som man åbenbart skal have tid til)! Hun henholder sig navnlig til Lord Digby, der hører til ovennævnte kreds, men hans heste er nok lidt dyre. Hun har altså adskillige opgaver for Disraeli. også modtagelsen af hans forfatterskab skal hun rapportere om, og der siges meget om det rundt om. Megen vægt lægger hun selv på veninden Margaret Trotters vurdering. Hun kopierer hendes votum om romanen "Contarini Flemming " og sender det til Disraeli. Også nu får han et pulver: "Let the saints talk - she has more true religion than any being I ever knew«. Hun gør, hvad hun kan for at vække Disraelis interesse for hende!

I det første brev efter valget, som Disraeli tabte, kommer hun også tilbage til sin veninde, men først vil hun trøste ham. Hun er hverken skuffet eller overrasket - man kunne jo ikke vente andet af ignorante vælgere. Men Disraeli har fremtiden for sig. Hans dag skal nok komme. Imidlertid skal der om aftenen være et stort maskeradebal, og hun ville ønske, at han kunne være med i sin pragtfulde tyrkiske dragt. Selv tænker hun på at sende oberst Grey, valgets sejrherre, en narrehue, som han kan bære første gang han er til maskerade som parlamentsmedlem.

Så vil hun besøge Margaret Trotter, som hun ønsker han vil gøre til heltinden i en roman, og hvis hun selv også kommer med i den, skal han ikke spare hendes fejl og dog være skånsom i sin kritik. "I call this impertinent, never mind, I am odd-". Selv vil hun altså gerne være genstand for hans interesse! Hun sender mange hilsener til familien, men især til Sarah: "I quite long to see her - one of the few I care to know ". Men der forlyder intet om, at Sarah har et lignende ønske.

Der foreligger endnu to breve, fra tiden efter valget $i$ juni. De er antagelig skrevet i november, $i$ hvert fald er det sidste dateret 19.11. I det næstsidste er der ikke noget særligt bemærkelsesværdigt, men hun fortæller dog bl.a., at baron Habers politiske indflydelse er voksende blandt toryerne - og at den stakkels Walter Scott nu ikke kan leve mange dage. Hun slutter med endnu en anbefaling af Margaret Trotter: "... all her fine feelings are 
thrown back and she with all her brilliant qualities and splendid fortune there she is a lone solitary creature ". Disraelibiograferne mener, at det er på grund af formuen, hun anbefaler den forgældede Disraeli pigen. Bradford siger (s. 48): "Acutely materialistic as she was " foreslog hun ham sin veninde. At hun var særlig "materialistisk " er der nu intet, der tyder på. Men at Disraeli ser sagen fra den kant, er oplagt. Han fik undersøgt, at "the fair Margaret" kun repræsenterede 20.000 pund, "why I am not in hüry" (s. 49).

Sarah Disraeli, hvis mening broderen lyttede meget til, havde en anden kandidat, sin afdøde kærestes søster Ellen Meredith. Hun sagde nej til ham i maj 1833. I samme måned skrev han til Sarah: "By the bye would you like Lady Z for sister-in-law, very clever, $25000 £$, and domestic? As for "love" all my friends who married for love and beauty either beat their wives or live apart from them. This is literally the case. I may commit many follies in life, but I never intend to marry for "love", which I am sure is a guarantee of infelicity" (Blake s. 94). Den omtalte Lady $\mathrm{Z}$, hvis navn var Charlotte Bertie, lærte Disraeli at kende i den teaterloge, hvor hendes veninde Lady Sykes sad sammen med ham. Lady $\mathrm{Z}$ blev meget betaget af ham, men det blev Henrietta Sykes, der sejrede.

Det sidste brev (19.11) fortæller bl.a., at Harriet Martineau er flyttet til byen, og alle toneangivende strømmer til hendes salon. Hun og Lady Blessington var de berømte midtpunkter i litterære og politiske kredse, og da Clara tilhørte disse kredse, tilbyder hun nu Disraeli adgang til Harriet Martineaus salon: "You must let me introduce you ....". Brevet giver imidlertid et særdeles levende indtryk af Clara som Disraelis valkyrie - han stiller sig for anden gang i High Wycombe, og nu under den nye ordning, hvor vælgertallet er blevet stærkt forøget. Hans chancer er dog stadig ikke store.

Men alle taler om ham. En morgen er hun sammen med en halv snes politikere af forskellig slags. De påstår, at Disraeli spiller dobbeltspil, at han ikke er virkelig engageret i noget, han vil kun være parlamentsmedlem. Man skulle tro, han havde været en gammel politiker, en der havde indflydelse og ikke en ny mand uden noget parti bag sig. Det sad hun stille og hørte på. Kun en af de tilstedeværende forsvarede ham. Men en anden sagde, at Dis- 
raeli kun havde ambitioner og blot ville være noget, og så kunne hun ikke holde det ud mere og svarede roligt: "Sir, should the result of Mr. Disraelis return be, that he is afterwards made premier, he will not be a greater man than he is now. Our poets and philosophers rank far before a pack of grovelling politicians. Had Mr. Dis. unfortunately been an idiot like his opponent Col. Grey he would not been subjected to the insults of fools, for they invariably appreciate their own order". The man made a jump. "Madame, is that applied to me?" "Most undoubtedly, Sir! You may think yourself lucky he has not the honour of answering your impertinent attack instead of myself. It would have been with other weapons". The thing grew serious, so off he walked, begging to shake me by the hand. I said: "I am not aware that it is a usual custom with a perfect stranger". After he left I got a fine Applause from the remaining vipers who saw it was no go. I give you the news as it will amuse you ".

Hun har været rasende og hendes "kulsorte" øjne har lynet

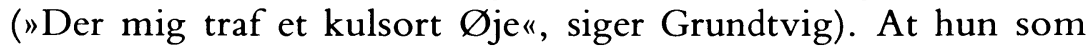
eneste kvinde i flokken har taget affære, har nok ikke været så sensationelt, som det ville have været i Danmark i 1832. Blåstrømperne havde længe virket i England på det tidspunkt. Kredsen omkring Lady Blessington bestod $i$ høj grad af emanciperede damer. Clara stod ikke tilbage for nogen af dem. Det citerede ordskifte viser hendes temperament, men også den suverænitet, der sikkert har været karakteristisk for hende.

- Valgkampen har bragt hende nærmere til Disraeli, så hun ikke længere er usikker over for ham. Hun føler, at hun virkelig har været ham til nytte, selv om han har tabt slaget. Hun er vis på, at han en dag vil sejre.

- C. B.s breve kan selvfølgelig bedømmes forskelligt. De er skrevet for 150 år siden og $i$ en anden kultur, og denne afstand gør også Blake usikker. Oscar Wood og jeg diskuterede brevene med ham, og vi var uenige med ham i bedømmelsen. Han troede på traditionen fra Sir Philip Rose om det intime forhold mellem D. og C. - vi tvivlede på den. Jeg kan heller ikke give Blake ret $\mathrm{i}$, at brevene "do in some indefinable way give the impression of brassiness and a certain vulgarity". Han har kun læst dem for at hente citater ud af dem, ikke for at lære hende at kende og om muligt efterspore en vis udvikling $\mathrm{i}$ hendes forhold til $\mathrm{D}$. Jeg 
fortalte ham om mit syn på Clara Boltons betydning for Grundtvig, og det har åbenbart modificeret hans karakteristik af hende: "... she was evidently not stupid and she moved in circles which had some claim to being both intellectual and cosmopolitan". Han nævner Alexander d'Arblay som hendes ven og siger, at Disraeli ikke var den eneste "man of genius ", som var tiltrukket af hende, og nævner så Grundtvig, "the famous Danish clergyman, philosopher and educationalist" og den inspiration, han kom til at skylde hende. Konklusionen bliver da: "There must have been more to her than one would deduce by reading her letters or the letters about her in D.s papers".

Det er Philip Rose's kommentar til brevene fra 1882, Disraelibiograferne bygger på. Den hviler på rygter, der dengang var 50 år gamle. Hertil kommer, at det billede, vi derudover får af ægteparret Bolton, skyldes Claras fjender, først og fremmest den kvinde, der fra foråret 1833 blev Disraelis elskerinde, Henrietta Sykes. Det ser ud, som om Claras brev af 19.11.1832 er det sidste vidnesbyrd om personlig kontakt mellem hende og D. Han har ikke mere haft brug for hende og har afskrevet hende. Så skifter hun også syn på ham. Muligvis har hun nu også selv fået øje for, at han er en politisk stræber - som hendes modpart i den tidligere refererede debat påstod.

\section{Bruddet}

Disraelis forhold til Henrietta Sykes havde en helt anden karakter end forholdet til Clara Bolton, selv om han efter tre års forløb også afskrev hende, stadig af hensyn til sine karrieremuligheder. Hun var gift (1821) med baron Francis Sykes, en meget velstående mand med et svagt helbred og en svag karakter. Med ham fik hun fire børn. Hun var iflg. Blake (s. 96) "a headstrong, wilful and passionate woman", som han ikke kunne styre. Hun havde haft en affære med Charles Westmacott, udgiveren af skandalebladet "The Age", og nu kastede hun sig altså i armene på Disraeli, og forholdet blev almindelig kendt. Hendes far Henry Villebois af Marham var fortvivlet over forbindelsen og tryglede sin datter om at opgive den, men hun henholdt sig til, at hendes mand accepterede forbindelsen. Sarah Disraeli inviterede hende 
til Bradenham, fuld af nervøsitet, men hun regnede nok med, at hendes broder havde brug for at blive knyttet til de fornemmere kredse. Det viste sig dog, at parret vakte forargelse på egnen, og som nævnt kom affæren Disraeli til skade politisk. Men han var virkelig forelsket. Hun "provided him with the "snowy bosom" which he craved" (Jerman s. 193).

Det har været $\mathrm{i}$ de tidlige måneder $\mathrm{i} 1833$, at han knyttede forbindelsen med hende (i april, mener Blake s. 97). Man hører intet om hans forhold til Clara Bolton efter hendes brev af 19.11.1832. Han tabte igen valget $i$ High Wycombe $d$. 12.12.1832, og det er da muligt, at han afbrød forbindelsen med hende, nu da han ikke mere havde brug for hende. Men de skulle mødes igen!

Jerman gengiver (s. 200ff) et brev fra Henrietta Sykes til Disraeli, der må være sendt i september 1833 . Hun siger, at hun har følt, at en storm snart ville bryde ud over deres hoveder, og at Clara Bolton stod bag, idet hun åbenbart prøvede at vende den vaklende baron mod Disraeli. Først skrev Henrietta Sykes et dusin noter til "Madame" (C. B.), nogle for varme, andre for kolde, og kasserede dem alle for så i stedet at opsøge hende personligt, og hun havde heldet med sig: hun fandt sin mands køretøj uden for Clara Boltons dør! Uden at banke på gik hun op og fandt dem begge i salonen. Hendes mand var nær besvimet. Lady Sykes selv var stiv som en ildrager og fuldstændig kold. Så sagde hun: "Mrs. Bolton, I have called upon you in consequence of a scene which I am perfectly aware I owe entirely to you and I am here to have an understanding ". Videre sagde hun: "Efter det, der er passeret, kan der ikke være nogen tilbageholdenhed mellem os tre. Sir Francis kender det fortrolige forhold mellem Disraeli og mig. Det har passet begge parter at være en hel del sammen og visselig ikke på grund af fortrolighed mellem damerne, for jeg har aldrig vist noget venskab over for Dem ... og når vi var sammen, udgjorde Disraeli og jeg og Sir Francis og De to adskilte parter, "and it can be proved, that we did ". Hvis han (Sir Francis) forlader London i morgen, vil jeg aldrig overskride Deres dørtærskel. Og jeg fordrer af ham, at han ikke med uretfærdige og uædle trusler krænker bånd, som han selv har sanktioneret, og som både han og De selv ved har været nødvendige, for at De kunne drive Deres spil«. 
Lady Sykes er overbevist om, at det er Mrs. Bolton, der står bag de ubehageligheder, der møder hende fra Sir Francis's side hun kender ham gennem 11 år! Men før hun forlader "this House«, må et højtideligt løfte afgives om aldrig at omtale Disraeli som "a bug bear"! Det er for lavt og foragteligt til at vække andet end "profound scorn".

Lady Sykes gengiver derefter, hvad Clara Bolton svarer hende, og man får på den måde at vide, hvordan hun nu ser på Disraeli: "You must be aware of the delicate position I am placed [in] with respect to Mr. Bolton, who considers me your friend «, og da jeg virkelig er knyttet til Dem, har det, at De ikke sympatiserer med mine følelser for Dem, forvoldt mig både smerte og overraskelse. "It was from disappointment I complained and not from malice". Nu får hun så luft for sin skuffelse: "Disraeli is a heartless wretch. I have stuck up with him for years. Our acquaintance has been of 9 ye[a]rs standing. Here are his letters vowing undying friendship, unspeakable obligation, but I repay them now with scorn ". - De - C. B. og Disraeli - har altså kendt hinanden i 9 år, idet hendes mand vel så længe har været læge for familien. I lange tider har hun gået $\mathrm{i}$ brechen for ham, og han har antagelig under valgkampen, hvor han havde brug for hende, lovet hende evigt venskab og usigelig forbundethed - som digter har han ikke sparet på ordene. Men man bemærker, at han ikke bruger ordet kærlighed. Nu har han imidlertid brudt venskabet, og hun foragter ham som en hjerteløs usling. Hun har gennemskuet ham.

Hvad forholdet til Lady Sykes angår, så har hun "for megen værdighed " til at ville placere deres bekendtskab på andet grundlag end det, hvorpå Ladyen selv har anbragt det. Hun klager over, at Disraeli har påvirket sin familie mod hende - hans far har aldrig besøgt hende. Men hun ved fra god kilde, at ingen vil besøge Lady Sykes næste år på grund af Disraeli. Men "he will leave you, he has left you, I know him well - he is everywhere despised ...".

Det er egentlig forbavsende, at Henriettas referat af Clara virker så pålideligt! Ordene har prentet sig hos hende - og har gjort indtryk på hende. Claras øjne har lynet, og hun har virkelig fået luft for sin skuffelse, og man tror hende, at det ikke er ondskab, hun har talt ud af. Hun er virkelig bitter, og det forstår man godt, når man har læst hendes breve til Disraeli. Hendes stolthed er 
blevet krænket. Men hun står ikke alene. Som eksempel på den modvilje, Disraeli er genstand for, citerer hun nogle ord af sin veninde forfatterinden Caroline Norton (gift med digteren George Norton), en af de tre berømte Sheridansøstre. Det blev Lady Sykes oprørt over - men vil ikke over for Disraeli repetere sin veltalende protest mod falskheden (Mrs. Nortons eller Mrs. Boltons?). Det er nok for hende og hendes elskede, "that we are victorious": "Madame cried and wrung her hands. F(rancis) cried and begged me to be merciful. I did not cry and had apologies from both".

Ja, man kan tænke sig, at Clara Bolton har grædt af harme over Disraeli, og den svage baron har grædt af svaghed i forholdet til sin stærke kone, der selvfølgelig ikke har grædt. Clara vred sine hænder, sikkert ikke fordi hun har fortrudt, hvad hun har sagt, men over at hun har kunnet tro på Disraeli. Hun fik ret $i$, at han også ville forlade Henrietta Sykes. Det gjorde han 3 år efter. Da overlod han hende til politikeren Lord Lyndhurst, som han mente kunne fremme hans politiske karriere.

Men i 1833 havde han virkelig følt sig lykkelig, hvad der fremgår af "the Mutilated Diary", som han påbegyndte 1.9. Her hedder det: "... one incident indeed made this year the happiest of my life. How long will those feelings last! « Han tilføjer, at de har bestået en stor prøve, "and now absence, perhaps the most fatal of all". - Der kan vist ikke være tvivl om, at hans lykke skyldes forholdet til Henrietta. Det kan nok ikke have noget på sig, at den store prøve skyldes Clara Bolton, som Blake formoder (s. 104). Hun er vist forlængst ude af billedet. Når han så spørger sig selv, hvor længe hans følelser vil vare, røber det en tvivl angående forholdet til Henrietta. Måske har hun selv mærket den tvivl. Hun slutter brevet om opgøret med Clara Bolton: "Dearest, every throb of every pulse is for you and you are my breath, my very being. Love me for ever even as I love you". En sådan kærlighedserklæring har han ikke mødt fra Claras side, og selv har han altså kun tilbudt hende "friendship" og "obligation ".

Hvordan Sir Francis' forhold til Clara Bolton har været, er et spørgsmål. Han har i hvert fald søgt tilflugt hos hende, og hun har haft medlidenhed med ham, et svagt menneske som han var, både på den ene og den anden måde - han rejste ustandselig på kurrejser til udlandet, fra det ene sted til det andet, tit dog også på 
jagt nordpå. Rig var han. Philip Rose, der har kommenteret Disraelis forhold til både Clara og Henrietta, og som har gengivet de rygter, han hørte i den periode, hævder på det grundlag, at Clara Bolton levede under Sir Francis' beskyttelse "and, as I understood at the time, with the husband's knowledge and consent, who was said to derive a pecuniary benefit from the connection". Forholdet mellem Clara og hendes mand har nok ikke været særlig varmt, og det endte med, at hun rejste fra London. Men at baronen skulle have givet doktoren penge, lyder ikke troværdigt. Man har ikke indtryk af, at ægteparret Bolton savnede noget pekuniært. De har levet meget fashionabelt og i et fornemt kvarter. At hun besad "en stor uafhængig formue», som Grundtvig formodede, er ikke usandsynligt.

Henrietta Sykes havde sikkert ret i, at det var Clara Bolton, der stod bag det, som Sir Francis havde sagt om Disraeli, at han var en plage. I hvert fald har hun været imposant i sin vrede. Men at hun finder sin mand hos Clara, har hun jo ingen grund til at blive ophidset over. Bagved lurer der dog nok et kvindeligt fjendskab over for Disraelis tidligere veninde, som på sin side nok har nydt at være blevet Sir Francis' trøst i nøden. Havde der virkelig været et varmt forhold imellem dem, kunne Clara have opfordret ham til at lade sig skille. Den tanke fik han først siden og af en anden grund end Disraeli.

Højst ejendommeligt er det, når man lige har hørt om det voldsomme opgør mellem de to damer - at alle tre spiste sammen om aftenen i baronens hus! (Bradford s. 67). Desuden aftaler de at rejse til Paris sammen, hvad der sker d. 29.8. Disraeli kommer fra Bradenham for at tage afsked med dem! Kort efter påbegynder han "the Mutilated Diary", hvor han taler om sin store lykke og om sin tvivl på, hvor længe hans følelser vil vare. Men hurtigt fordyber han sig i drømme om sin glorværdige fremtid, selvoptaget, som han er. Imens er de tre altså på vej til Paris. Det har ikke været nogen idyllisk tur. 9.9. skriver Henrietta til Disraeli: "I hate Mrs. B. I think her a positive devil and [she] plays dreadfully on the feelings and sense of my husband «. Hun måtte også finde sig $\mathrm{i}$, at de to gjorde nar af D.s måde at gå på - når man gik bag efter ham, så han ud som en gammel mand, fordi han gik foroverbøjet! "I was quite in a rage", skriver hun. Clara kunne åbenbart ikke lade være med at drille hende. De skiftes til at gøre hinanden rasende. Og det fortsætter hjemme i England. 
Lady Sykes lejede et hus i den mondæne badeby Southend øst for London og inviterede Disraeli til at være deres gæst der. Sir Francis tilsluttede sig hjerteligt invitationen (11.10), men insisterede på, at Boltons også skulle inviteres - "the damnable Boltons", som Henrietta kaldte dem. Men 18.10. skriver hun glad til Disraeli: "Mrs. Bolton, thank Heaven, is off to Chertsey. The Lamberts appear to dote on her " (der er altså nogen, der forguder hende - ægteparret Lamberts omtales også i hendes breve), men hun fortsætter så: "She told me she intended going to Bradenham to see her dear friends. What is to be done? For she has impudence for anything ..." (Chertsey er ikke langt fra Bradenham). Det er igen et drilleri! Og det er vel ikke andet, for Henrietta må vel vide, at familien i Bradenham ikke er hendes venner. Men hun skal pines og er et taknemmeligt offer. Og nu kommer hendes plageånd til Southend! Hun skriver: "The greatest drawback will be the damnable Boltons. They poison love, my greatest source of enjoyment ".

Lidt ind i november ankommer Disraeli. Henrietta forsikrer, at det er gået meget godt i Southend. Hun styrer det hele med fast hånd: "My word is law, my look is a command ". Men da Disraeli er rejst, skriver hun, at hun hvert minut plages af "the coarse vulgarity of the one, and the hypocrisy of the other ". Blake morer sig med at give et rids af dette "curious household " i Southend: "Sir Francis, weak and affable; Dr. Bolton, ill-bred and familiar; Mrs. Bolton, brassy and overdressed; Henrietta, condescending and grand; Disraeli, silent and cryptic. It suited all parties concerned to preserve a veneer of civility, but beneath it passions seeded «. Det sidste skal nok passe. Hvad karakteristikken i øvrigt angår, ved Blake vist for lidt om doktoren, og når han kalder Clara "overdressed", bygger han det på en upålidelig kilde nemlig Henrietta, der har skrevet til Disraeli: "Mrs. Bolton is a mass of splendour - where the money to pay it (comes from) is an awful question". Hun insinuerer uden tvivl, at det er hendes mand, der har betalt. Men selv om Clara sikkert har haft et rigt udvalg af rober derhjemme (jfr. alle hendes fester), har hun nok anstrengt sig ekstra til lejligheden, for hun ved, hvordan Ladyen klæder sig. Der findes hos Blake (s. 100) en gengivelse af et maleri af Henrietta, malet af den skotske portrætmaler Daniel Maclise, hvor hun fremtræder som en kejserinde, i fløjl til gulvet, med 
brokade, hermelin og smykker, pragtfuld at skue. Clara har trods alle sine anstrengelser umuligt kunnet konkurrere med hende. Ladyen har haft let ved at fremtræde som "condescending and grand ".

Men Clara kan have haft en særlig anledning til sine drillerier, idet hendes intelligens nok har overgået Henriettas. Iflg. den førnævnte Charlotte Bertie var denne "a fine and good-natured woman ", men Blake karakteriserer hende anderledes - ud fra sit kendskab til hendes breve: hun var "basically a passionate, emotional, jealous, highly sexed woman, who wanted a lover", og Sarah Bradford supplerer med at hævde, at hun var "by no means an intellectual" (s. 64). Der har været rig anledning til spændinger imellem de to.

Folk, der kendte dem begge, har selvfølgelig også taget parti. Medens the Lamberts altså forgudede Clara, skriver Henrietta til Disraeli, at en af hendes bekendte "Mr. Hamond ... as good as told me that Madame was "an untruth from beginning to end and hinted that Monsieur B. was artful ...". Jeg har faktisk støvsuget materialet for at fo alle udtalelser om Clara samlet sammen, så man selv kan danne sig et indtryk.

Men der er flere kilder. Sarah Bradford er ikke ganske pålidelig i sin behandling af dem, f.e. med hensyn til at læse navne i Claras breve. Men værst er det at hun har dateret et brev fra Sarah Disraeli til broderen forkert. Hun læser 1833 i stedet for 1835 i datoangivelsen og hævder af den grund, at Clara fra november 1832 til april 1833 opholder sig i Haag og derfra vender hjem til det dramatiske efterår. Men sagen forholder sig sådan:

I marts 1835 skriver Sarah til broderen, at præsten i Bradenham Isaac King har henvendt sig til hende $i$ anledning af et brev, han har fået fra kapellanen i Rotterdam (velsagtens den engelske præst) med forespørgsel om, hvem Mrs. Buckley Bolton er. Hun ankom til Haag i november 1834 uden nogen introduktion eller kvindelig ledsager og indlogerede sig på et hotel, hvor hun siden har boet og været genstand for stor nysgerrighed og, "som den fromme mand venligt antyder", megen forargelse. Hun synes imidlertid at have udmærket sig ved stadig deltagelse i gudstjenesten og ved at vise stor opmærksomhed over for gejstligheden. Præsten er øjensynlig meget interesseret $i$ hende og ivrig efter at fa at vide, "in profane parlance, who the devil she is ". Hvis hun 
er lige så uskyldig, som hun er interessant, vil han få ambassadøren og andre til at støtte hende, men hvis hun er "guilty", vil han måske gøre noget for hendes sjæl, skønt han på det punkt synes noget forvirret. Hun har ikke angivet, hvem hendes mand er, men siger, at hun har været gift i 7 år. Blandt andre "pralerier" (rodomontades) har hun fortalt, at hun selv alene finansierer en søndagsskole og en anden sammen med familien Disraeli. Hun har åbenbart talt om Isaac King, som om hun var nært knyttet til ham.

Han har været bortrejst, har han meddelt Sarah, så hans svar vil blive forsinket, men han vil gerne vide, hvad han skal svare, bl.a. "everything I could say in her favour". Sarah havde svaret, at hun ikke vidste nogetsomhelst om Mrs. Bolton, at "broderen havde ønsket at vise hende nogen opmærksomhed, til tak for den store opmærksomhed, han selv havde modtaget under lang sygdom, at resultatet var et besøg, der varede lidt længere, end vi havde ventet, at vi derefter hverken havde set hende eller hendes mand i nu næsten 5 år".

Hun skriver ikke, at broderen havde bedt hende invitere Mrs. Bolton til Bradenham i 1832. I det hele taget lægger hun luft mellem hende og familien - i loyalitet over for broderen, der jo forlængst har afskrevet hende. Uklart er det, om hun stadig har samarbejde med familien om søndagsskolen. Når Sarah i den forbindelse taler om pralerier, er der jo ikke dermed sagt, at det ikke er rigtigt, hvad hun har fortalt. Bl.a. er det rigtigt, at C. B. har kendt Isaac King og hans familie godt, for hun nævner dem tit i brevene - bl.a. som uvillige til at stemme på Disraeli!

Men hvorfor er hun rejst til Haag? Vi ved intet om hende i 1834, heller ikke om hun skulle være blevet skilt, og det har hun altså heller ikke fortalt i Haag, hvor hun udtrykkelig har kaldt sig Buckley Bolton og sagt, at hun var gift. Sarah Bradford antyder, at hendes ven baron Haber jo havde sin virksomhed i Haag, men hvis det havde haft nogen betydning, havde man i den godt orienterede engelske menighed vel ikke haft indtryk af, at hun var helt isoleret $\mathrm{i}$ byen, så at hun gjorde alt for at få tilknytning til menigheden og gejstligheden i Rotterdam, som vel også betjente Haag.

Men Clara har altså forladt London og vel også sin mand. Det kan hænge sammen med, at Sir Francis i foråret 1834 tog på en 
lang tur til kontinentet, og at Disraeli ledsagede ham til Harwich. De var nu på god fod med hinanden. Iflg. Bradford (s. 72) synes Sir Francis at være blevet desillusioneret i forholdet til parret Bolton. Han har nu omtalt det som "the dreadful people in King Street ". Om doktoren sagde han, at han var "a double-faced villain ", og hans følelser over for Clara var nu "those of disgust ". Disraeli har helt fået overtaget over den svage mand. Han overlod nu sin kone til Disraelis omsorg og understøttede hende med et fast årligt beløb til lejligheden og børnene. Disraeli selv havde ingen penge, kun gæld. Kreditorerne sværmede omkring ham.

Sir Francis fandt sig også i, at Disraeli, der som næunt havde brug for Lord Lyndhurst's støtte til at komme i parlamentet, overlod Henrietta til Lorden, hvad der vakte almindelig forargelse. Først da baronen i juli 1837 fandt sin kone i seng med den store flotte skotte Maclise, som havde malet hende, mens han selv var i udlandet, reagerede han. Rasende anlagde han sag mod Maclise for "criminal conversation" (sådan udtrykte man det juridisk) men han opgav sagen, muligvis fordi så meget andet ville blive hvirvlet op, hvis den blev gennemført. Disraeli var i hvert fald lettet og glad! Han havde nu ganske opgivet forholdet til Henrietta, som nu var helt udstødt af det gode selskab. Hun døde i 1846, samme dag Disraeli som parlamentsmedlem holdt en af sine mest glimrende taler.

Clara, hans første middel til at komme frem i verden, var død 7 år før. Hans sidste ord om hende - de står i hans dagbog for 1834 - var denne karakteristik: "a decoy duck " - en lokkeand eller lokkedue (Blake s. 76). Hvad det så ellers betyder! Hans biografer forstår det sådan, at hun skulle lokke rige klienter til sin mand, men det lyder ikke sandsynligt, da han iflg. Bradford var rig og boede fornemt. Intet i Claras breve tyder i retning af, at hun på den måde var en lokkedue. Derimod søgte hun af al magt at lokke folk til at stemme på Disraeli - men det kunne han jo ikke have noget imod. Har han selv følt sig lokket af hende? Han har i hvert fald følt sig draget af hendes milieu og hendes hjem, hvis fester han foretrak frem for sammenkomsterne i Londons klubber, for slet ikke at tale om stilen i sit eget hjem i Bradenham med dets "cold coffee and colder women". Hun indførte ham i "de bedre kredse «. Og så ville hun jo lokke ham til at gifte sig! Men han bed ikke på krogen. Selvfølgelig kan man som sagt spørge, om han 
følte sig draget af hende selv, og det kan have næret en frygt hos den jaloux Henrietta, som flere gange bad Disraeli forsikre hende om, at det med Clara var helt forbi. Hun har nok mærket, at Clara Bolton var en stærk personlighed.

Og så var hun yngre. Ved sin død var hun 35 år. Her har jeg fået hjælp af Det danske Selskabs udsending i Rouen Bent Jorgensen, som med stort besvær fik opsporet hendes data gennem amtsarkivet i Rouen. Sarah Disraeli skrev 3.12.1839 til broderen, at hun havde læst, at Mrs. Bolton var død i Le Havre. Der stod nemlig i The Times d.27.9.1839 (under døde): "Lately at Havre-de-Grace Clarissa Marion, wife of George Buckley Bolton, Esq. of Pall Mall ". Hvad betød "lately «? Først var der den vanskelighed, at registrationen af døde var bombet bort i Le Havre, men det viste sig, at der var kopier i Rouen. Alligevel glippede mit første forsøg på at nå frem. Men så lykkedes det for Bent Jørgensen, idet det viste sig, at man skulle helt tilbage til juni 1839. Af dødsattesten fremgår det, at Clarissa Marion Verbecke afgik ved døden kl. 1 om morgenen den 29. juni 1839 i Hotel des Bains Frascati i Duperrey-kvarteret i Ingouville (en kommune, der senere blev sammenlagt med Le Havre) $i$ en alder af 35 år. Hun var født $i$ Bread Street i London som legitim datter af Michael Peter Verbecke og Clarissa De Brabandes. "Hustru til Buckley Bolton". Iflg. protokollen var hun således ikke skilt.

Hun er altså født i 1804 (1805) i det indre London. Bread Street ligger lige øst for St. Paul's, men blev bombet ud under krigen. I dag ligger der store bankbygninger i stedet for de gamle huse $i$ den krogede gade. Forældrenes navne tyder på, at de har været af flamsk afstamning. ${ }^{3}$ Claras "kulsorte øje " kommer i så fald sydfra. Temperamentet nok ligeså og hendes kosmopolitiske indstilling måske også. Det har i hvert fald været naturligt for hende at give sig i snak med udlændingen Grundtvig efter middagen, og så gik det altså løs til henad klokken 1. Den 46-årige og den 26-årige har været på lige fod.

Men der foreligger endnu en kilde til belysning af, hvem hun var. 


\section{Clara og Alex}

En af Clara Boltons venner var Alexander d'Arblay, søn af den meget kendte forfatterinde Fanny Burney, der med sine romaner i slutningen af det 18. årh. siges at have banet vej for Jane Austen. En tid havde hun en stilling ved hoffet og havde til det sidste omgang med de kongelige. Hun var en meget flittig brevskriver. Så sent som i 1984 kom det 12. og sidste bind af hendes "Journals and Letters". Af de sidste er der trykt ikke mindre end $1529-$ og så er endda ikke alt taget med!

Det er Jens Peter Agidius, ansat ved Odense Universitet, der efter en studierejse til England, hvor han søgte at gå "i Grundtvigs spor ", har gjort mig opmærksom på en bog om Fanny Burney, skrevet af hovedudgiveren af hendes breve Joyce Hemlow, hvor der gengives et brev om Clara Bolton. Det er også trykt $i$ det nævnte bind 12 - foruden andre interessante oplysninger om Clara. I selve Fanny Burneys breve er der ikke meget at hente om hende. Men vi får hende at se, også på indirekte måde, i et helt andet lys end det, Disraelibøgerne har kastet over hende.

De to damer kender muligvis hinanden. Den første gang Clara Bolton omtales i Fanny Burney's breve, er i en efterskrift til et brev af 16.9.1828 (XII s. 719) til søsteren Mrs. Broome i Brighton, hvor $\mathrm{FB}$ påtænker et efterårsbesøg. Hun skal skaffe hende og sønnen en lille lejlighed, men Alex d'Arblay, der fra 1824 har været præst ved Camden Chapel i London, kan ikke sige, hvornår han kan gøre sig fri. Der kommer senere besked, og så kommer efterskriften: "The Gentlewoman's Name per Baggage and per Mail will be Mrs. Bolton «. Der er ingen kommentar til denne mystiske tilføjelse.

$\mathrm{Nu}$ ved udgiverne ikke, at Alex d'Arblay og Clara Bolton kender hinanden. Det har de uden tvivl gjort i 1828, 4 år før CB's omtale af ham som en nær ven i 1832. d'Arblay var et rodehovede og meget verdensfjern, og CB kan have tilbudt at hjælpe ham ved afrejsen til Brighton med at få sendt baggage og besked om hans ankomst. $\mathrm{FB}$ må $\mathrm{i}$ hvert fald have vidst noget om hans bekendtskab med CB.

Nogle ord om Alexander d'Arblay. Han var søn af en fransk general, der allerede døde i 1818. FB's forfatternavn var Burney, men hun hed altså d'Arblay og kaldte sig også sådan. Hun havde 
kun det ene barn og var med rette fuld af bekymringer for ham. Han havde et kapellanembede $i$ et stort og voksende forstadssogn, men hun frygtede for, at han skulle være alt for upræcis og bekymringsløs over for alle sine pligter som præst. London kunne han ikke undvære på grund af alle de litterære, videnskabelige og sociale bånd, der knyttede ham til byen. Derfor ville han blive boende hos sin mor og kun opholde sig den nødvendigste tid i nærheden af sit arbejdssted. Så ville moderen prøve at holde styr på denne "digter og teolog" af en søn (XI s. 521). Han havde f.eks. slet ingen forstand på penge (XII s. 723).

Og var han endda gift! I 1826 var han ulykkeligt forelsket i en kusine (XII s. 672 n.6), men i 1828 klager hans mor (s. 726): "Hvor usigeligt længes jeg efter at se ham lænket. Godt lænket, naturligvis! « I maj 1830 gentager hun sin klage. Han er da 36 år (født i 1794).

I 1831 søger han et mindre (ekstra?) embede ved hittebørnshospitalet i London, hvad der vil indbringe ham 50 pund - kapellanembedet giver ham 200 pund. En note (s. 752) oplyser, at Clara Bolton i et brev til Disraeli skrevet før 14.11.1831 har bedt om hans hjælp: "Can you assist me, by any interest you may have in the Foundling Hospital? one of my most particular friends a man well worth of your notice is canvassing for the duty, a Mr. d'Arblay son of the celebrated "Miss Burney" he is a really talented orthodox creature, a beautiful poet. I never heard so fine a reader, he preaches now at one of the new churches ... perhaps $\mathrm{Mr}$. Disraeli may know some of the committee ... we have great fears «. Det er det første brev, der kendes fra CB's hånd, og vel også det første brev til Disraeli. Han har, hvis datoen er rigtig, făet det lige efter sin hjemkomst fra sin store rejse, og det kan have givet anledning til den følgende korrespondance i 1832. Den nævnte Disraeli er sikkert Benjamins far. d'Arblay fik ikke embedet.

I 1832 trækker det op til, at folk i hans menighed vil klage over hans forsømmelser. Han er borte et par måneder, måske i Paris, hvor han muligvis har friet til en engelsk præstedatter, hvis fader dog kasserede ham som svigersøn, antagelig p.gr. af hans fattigdom. Han var selv rig. Alex skriver i hvert fald sørgedigte over den bedrageriske verden - men også andre digte og salmer (s. 810). En biskop, der kendte hans poetiske evner og åbenbart 
ville opmuntre ham, opfordrede ham til at sætte Davids salmer på syngelige vers, og han efterlod sig da også i hundredevis af forsøg. De prædikener, som han udgav, er også i den høje poetiske stil, og i Clara Bolton havde han altså en stor beundrer. Hun må have hørt ham i Camden Chapel.

Fanny Burney sukker i juli 1834: "Skal jeg aldrig have den lykke at se ham velsignet med en passende ledsager?« Men så sker der endelig noget. Et forvarsel kommer i et brev af 26.1.1835. I forbifarten hedder det: "Alex is just returned from Dover « - ikke andet. Hvad han skulle der, står der intet om, Men det skulle vise sig, at hans gamle veninde Clara nu havde slået sig ned der. Har hun inviteret ham? FB nævner kun een gang før, at han har besøgt Dover. 18.1.1825 skriver hun: "Alex is at Dover - on a little invited excursion, and to preach, I think, yesterday at the request of Lady Combermere" (s. 574). Hun var iflg. FB netop blevet skilt. Hun havde litterære interesser og tilhørte den emanciperede kreds omkring Lady Blessington, og hun havde altså slået sig ned i Dover.

Fanny Burney og Lady Combermere kendte hinanden, jfr. invitationen til Alex i 1825, og i Dover (om ikke allerede i London) gjorde Clara Bolton bekendtskab med hende. Det står i et brev, som FB's halvsøster Sarah Harriet Burney har skrevet 23.1.1835 til Mrs. Grosvenor, en bekendt af FB. Brevet er gengivet i en note s. 852 og rummer vist den eneste karakteristik af Clara Bolton, der forekommer - bortset fra Disraelibiografiernes ensidige bedømmelse af hende. I hvert fald fremstilles hun i et nyt lys, og man forstår bedre, at hun har været $i$ stand til at fascinere Grundtvig.

Noten oplyser som indledning til brevet, at der i Dover på den tid var en litterær kreds, hvis midtpunkt var en " Clara" Bolton or Clarissa Marion neé Verbeke (ca. 1804-39), wife of the surgeon George Buckley Bolton (c. 1797-1847) of King Street, St. James Square". Ved henvendelse til udgiverne af FB's breve har jeg søgt at få oplysning om, hvorfra de har Claras pigenavn (anderledes stavet end i dødsattesten) og hendes fødeår, men de har ikke svaret. Skulle der virkelig være andre kilder til oplysning om hende? For de nævnte udgivere er hun kun en uvæsentlig bifigur.

Med henvisning til Robert Blakes Disraelibiografi slår de fast, 
at $\mathrm{CB}$ var "the mistress formerly of Disraeli", og at hun tiltrak en gruppe af "eminent and accomplished men". Foruden Disraeli og d'Arblay nævner Blake kun Grundtvig i denne forbindelse så indirekte er han altså kommet med i udgaven af FB's breve!

Udgiverne tager imidlertid fejl, når de tror, at Disraelis roman "Henrietta Temple" har portrætteret Clara Bolton. De synes ikke at kende Henrietta Sykes, som gav navn til romanen, der i øvrigt er skrevet, efter at forbindelsen mellem CB og Disraeli var ophørt.

Men til brevet! Sarah Harriet Burney skriver: "Pray, do you know a Mrs. Bolton, wife of a doctor of that Ilk [samme navn]? She is reported to be very handsome, immoderately clever, an Astrologer, even, that draws out ... Nativities, and is besides poetry-mad, and has conceived a mad fancy for Alex d'Arblay. She is now at Dover, deprived for the present of the use of her limbs, but certainly not of her tongue, which goes nineteen to the dozen. She is carried on an inclined plane to peoples houses of an evening, and has struck up an acquaintance with Lady Combermere, where Harriet Crewe saw her. She is very entertaining, and has something of the look of a handsome witch. Lady Combermere calls her The Sybil».

Det er altså Harriet Crewe (i index benævnt Henrietta), der er iagttageren af Clara Bolton. Hun var født i 1808 og var altså 4 år yngre end Clara. Hun var Sarah Harriet Burneys gamle elev og en fortrolig veninde af hende. Men det er jo et spændende indtryk, hun har fået af "Sibyllen", så spændende, at hendes gamle venindes nysgerrighed er blevet vakt. Hun er meget smuk, er overordentlig velbegavet, hun er meget talende og underholden$\mathrm{de}$ - og så kan hun stille horoskoper! Hun ligner noget i retning af en smuk heks, og værtinden Lady Combermere kalder hende altså "sibyllen ", velsagtens i forbindelse med hendes astrologiske evner. En vis distance kommer til orde hos den yngre overfor den lidt ældre: hun er poesigal - det er Harriet nok ikke. Og så er hun forgabet i Alex d'Arblay! Ja, han har nok foldet sig ud på det høje poetiske niveau, men selv om hun er betaget af hans poetiske gaver, er det nok snarere ham, der er forgabet i hende. Man behøver kun at tilføje Grundtvigs ord! „Da mig traf et kulsort øje " for - ved hjælp af Harriet Crewe - at begribe, at Grundtvig kan være blevet betaget, når det viste sig, at der ikke var den ting $i$ 
verden, de ikke kunne tale sammen om. Men det er da muligt, at hun har sagt det meste! "Immoderately clever" - ja, hun kan i debatten have været jævnbyrdig med Grundtvig. Ikke mindst poesien, myten, billedsproget kan have bragt dem på talefod.

Når hun tilbød at introducere Grundtvig hos sine litterære venner, kan hun også have tænkt på sin ven d'Arblay, hvis poetiske evner hun beundrede. I sit tredje brev til Disraeli fortæller hun, at hun en aften fik ham slæbt til en soiré, hvor han gjorde stor lykke: "He was a star and gave some splendid recitation from Racine's tragedies and an exact imitation of Jalina. I never saw anything finer. The foreigners were astonished and looked like educated monkeys ... ". - Jeg ved ikke hvad eller hvem Jalina var. En rolle i et af de skuespil, "alle" skulle se? En kendt skuespiller?

Harriet Crewe fortæller, at Clara Bolton for tiden er syg og må bæres rundt. Som vi har hørt det, var hun også syg i 1832, og hun er jo nok død af en sygdom (kun 35 år gammel) - måske af tuberkulose, som mange dengang døde af. Men det synes altså at være midlertidigt, at hun i Dover ikke kunne bruge sine lemmer. Det kan dog have gjort hende til genstand for endnu større opmærksomhed.

Brevenes udgiver beretter som nævnt, at hun er centrum i den litterære kreds i Dover, og ordene "she is now at Dover" viser, at hun først for nylig er kommet der. Hvorfra? Åbenbart fra Haag, hvortil hun kom i november 1834, jfr. Sarah Disraelis brev til broderen af marts 1835. Brevet fra Rotterdam til Isaac King i Bradenham kan godt være sendt allerede $i$ januar, men præsten $i$ Rotterdam kan ikke i tide have nået at få svar, for hun må være rejst i samme måned. Så nysgerrigheden i Haag kan ikke være blevet tilfredstillet. Det kan være, at Clara er flygtet for den. Underligt er det, at hun benævnes "centrum" i Doverkredsen, når hun ikke har boet der ret længe. Har hun med det samme startet en kreds? Eller er hun søgt til Dover, fordi hun kendte kredsen der? Det kommer der nok ikke svar på.

Udgivernes indholdsrige note er knyttet til FB's korte bemærkning i brevet af 26.1.1835, at Alex netop er vendt hjem fra Dover. Men først i FB’s næste brev til søsteren viser det sig, hvad grunden er til hans udflugt til Dover. FB skriver: "Alex returned from Dover in high health and spirits, but thinner than ever - he had sat up to 3 or 4 in the morning, making society verses. His 
imprudence is unprecedented, and very hardly it works me ...". Om nattesædet må han have fortalt sin mor - men hvor meget mere har han fortalt?

En note oplyser (s. 855), at der må være tale om en ballade med hele 46 strofer, som han lod trykke i Dover, tilegnet Mrs. Buckley Bolton! I forordet retter han en undskyldning til digteren Campbell, hvis ballade hans egen er en parodi på. Forordet er skrevet 1.2., så han har villet aflevere sin hyldest til Clara med det samme. Hun havde sunget Campbells ballade ved et aftenselskab, hvor adskillige store børn havde leget en spændende leg: de skulle forskrække hinanden i et mørkt værelse ved mystiske besværgelser og med spøgelseshistorier i tilknytning til den ballade, som Clara har sunget som akkompagnement til legen, som hun nok selv har arrangeret. Hun var jo vant til selskabslege i London. Alex, der har været med, er blevet opflammet til at parodiere balladen - og har straks udgivet sit værk og tilegnet det til hende, der har inspireret ham.

To måneder efter Doverrejsen får Alex en ordentlig skylle fra sin mor. "Hvad betyder din opførsel ", spørger hun. Hun er såret, hun der stadig har søgt at bøde på hans fejl og glemsomhed og hjælpe ham økonomisk. "What a Change! "Og hvorfor skrev du forleden dag: "My nature is so affectionate - ". "To whom, Alex? " Hun fristes til at overlade ham til hans egen skæbne, fordi han ikke svarer på hendes breve. Men sagen er nok den, at han er forelsket. Men i hvem?

En måned efter skriver hun et nyt brev med flg. adresse: "The Reverend A. d'Arblay, Clarence Hotel, Pier, Dover, or to the care of Mrs. Bolton. If gone, or not there, to be sent back to ..." ". Han og Clara bor åbenbart på samme hotel. FB's brev begynder: "Take my tenderest and delighted Benediction, my dearest dearest Alex -«. Han er altså blevet forlovet. Men med hvem? Hun fortsætter: "That I should feel - though personally in the dark - perfectly satisfied of your happy lot, I have but to recollect your own words - which you read to me - addressed to your kind and partial friend Mrs. Bolton, "that you believed no one a more competent Judge than herself of what best would suit your taste". Og hvad angår hans mors godkendelse, vil hun gengive hans egne ord til hende selv: "I would give Worlds you could see her! I think her the person above all others I have met with that 
you, my Madre, would prefer for me ...«. Han priser pigens "sweetness and innocense".

For at nå frem til, hvem den udvalgte er, må jeg først nævne to brevudkast, som udgiverne har aftrykt i en note s. 865, og som jeg tror de har misforstået. De er skrevet af Alex og er rettet til Clara Bolton, men de bliver her kun tolket ud fra, hvad der er sket i Dover. Udgiverne ved nemlig ikke, at de to har kendt hinanden i London. De mener, at Alex efter "the fun and games at Dover" nu søger "to call a halt to the possessive and tenacious tendencies to the sorceress and offer a new kind of friendship" med C. B. Men brevudkastet røber en meget dybere baggrund: "I resolved to examine my own heart, to divest myself of self, and to look back on all our past friendship with a prospect, if possible, to a better future. I thought, to use your own words, how little like a rational being I had appeared - how much energy of mind and of feeling, in both, had been frittered away upon a useless abstraction of sentiment - that could, from the position, lead to no result, save a protracted and painful moral struggle - I felt that I had too long sacrified duty to inclination - and made my sympathy towards you my predominant consideration, instead of ... consulting my friend's permanent interests ".

Der må have fundet et slags opgør sted imellem dem, hvor hun har bebrejdet ham hans følelsessværmeri i forholdet til hende. Han har ikke optrådt som et fornuftsvæsen, og han giver hende ret. Han har ofret pligten for sin egen tilbøjelighed for hende pligt og fornuft er nok to sider af samme sag for ham og også for hende! Han har mere tænkt på sig selv end på hendes vel.

Hvis der nu, som udgiverne formoder, er tale om to udkast (de ligger i et bibliotek i New York), er det første nu sluttet, og det andet begynder: "Henceforth, dear Clara, see me in a new light. I revoke my former friendship to offer you a new one, reconstructed upon a more solid basis, and productive of a more lasting superstructure. Whether or not our destinies should, as I hope, throw us again together, my wish is now to devote, if you permit it, my best thoughts, my purest energies, to your welfare, in that way in which alone I may still hope to serve you ...".

Den rimeligste forklaring på hans selvopgør, der har resulteret i dette tilbud om en ny slags venskab, er vel den, at han har friet til hende og fået nej. Af en eller anden grund skal de nu skilles, 
måske fordi hun skal rejse. Derfor måtte deres forhold afklares. Men hvis de mødes igen, vil han helt stå til rådighed for hende og kun tænke på hendes vel. Han har indset, hvor selvoptaget han har været.

Men nu vil han åbenbart giftes. Har han selv truffet sit valg eller har Clara vejledt ham? I hvert fald har han rådspurgt hende, hvad brevet fra moderen om forlovelsen viser. Han har lagt sin sag i Claras hånd. Hun har skrevet et brev til ham, der er gengivet i en note s. 873 med overskriften "Ekstract from a letter of (Mrs.) B (perhaps Clara Bolton) rec. April 4 1835«:

"... My friend M. A. S. is very good and we often talk of you - I am convinced if you liked her and popped, you would be accepted - but I am no matchmaker - I never disguise the truth from either party, more especially when both are my friends - if I held out to you she was a genius, I should lie - nor is she enthusiastic - her nature is formed in a different mould - but no one I ever saw in the shape of her structure and character, possesses a rarer combination of amiabilities and plenty of talent if called forth her judgement is good and sound, and all she does is well principled and steady - there now - do you not intend giving us a look ere we leave - we may never meet again under such happy circumstances - the steamboat runs regularly to Dover and comes in one hour less than the coach - do come next week if (?) possible ...".

Det er det sidste brev, der kendes fra hendes hånd. Hverken Harriet Crewe's bedømmelse af hende eller dette brev tyder på nogen "vulgaritet" af den art, som Disraelibiograferne tillægger hende. Det er sin veninde, hun skriver om, og hun gør sig umage for at skrive sandfærdigt. Det synes som om hun er vant til at give råd i slige sager, men hun hævder, at hun ikke er nogen "Kirsten Giftekniv " - og så tænker man dog på hendes forsøg på 3 år før at få både Disraeli og Angerstein gift!

Imidlertid tror hun på, at hendes tilbeder og ven vil kunne passe sammen med hendes veninde, at han vil kunne kalde hendes talenter frem, og vel også at hun vil blive en nødvendig ballast for ham. Hun indbyder Alex til at komme en sidste gang til Dover, "ere we leave". Hvem er "vi«? Det er der ingen forklaring på. Men hun forsvinder nu ud af Alex's liv. Spørgsmålet er dog, om hun forsvinder ud af hans tanker. Det kommer jeg tilbage til. 
Men hvem er hendes stedfortræder? Til brevet med FB's velsignelse til sønnen er der føjet en note om hende (s. 864). Claras veninde hedder Mary Ann Smith og er antagelig lærerinde ved en privatskole i Dover med familie i Greenwich, men udgiverne tør ikke med sikkerhed identificere hende. Hun har været en tilbageholdende natur og har f.e. bedt om at fa sit navn slettet $i$ den første udgave af FB's breve (1842-7). En slægtning af FB karakteriserer hende $\mathrm{i}$ et brev (10.9.1838) som "very kind, gentle and pleasing - not really pretty, but nothing unpretty - a very nice sensible engaging creature".

I løbet af april måned frier han til hende og får hendes ja. 1.5. giver moderen ham sin velsignelse, men vanskelighederne tårner sig op. Man făr ikke noget klart billede af dem, men de galder både "finance and connection". FB ser så sent som 8.7. vanskeligheder, der er af så ekstraordinær natur, at de ville synes overdrevne, hvis man mødte dem "in a work of fiction". Hvad finanserne angår, ser det ikke godt ud: Alex's modstandere i sognet er ved at organisere sig, og selv om 90 af hans sognebørn undertegner en adresse til fordel for ham, tager han dog sin afsked midt $i$ juli (s. 872). FB's brev slutter: "My poor Alex gives me his quicksilver pulse and circulation ".

Men så er der en efterskrift: "I have seen the young Lady - and she has put me to Heaven! so much I like her - so much - much, that love is the only proper word!" Hun skulle da også blive en stor støtte for sin svigermor.

Alex gik det derimod dårligere og dårligere. I december klager FB over, at han hverken kommer eller skriver. Udgiverne føjer til dette brev en note med et citat af et udateret brev fra Alex, der måske er et svar på moderens klage. Det er fuldt af selvbebrejdelser. Men han frygter et mørke, der mer og mer tager magten i hans sind. "Poor generous May! Her fresh heart her happiness ought not to be put at stake at one whose spirit is broken whose soul is fled - How I admire her and the more I admire her how I feel wretched at the impossibility if now doing her justice as she deserves - ". Han klager også over, at han har svigtet sin mor, der alene kan søge at trøste ham. "O it is a madness - a delirium without a name". Udgiverne citerer også vers, der afspejler hans sindstilstand: "Perhaps it was "noble May", perhaps another, who had 
bid me strike the Lyre again

On whose accents you fondly hung

And I thought the breath of thy magic tongue

would awaken its boldest strain.

But oh young love's impassioned dream

No more in a worn out breast may glow

Nor an unpolluted stream

From a turged fountain flow."

Jeg tror ikke, at det var "Noble May" - Mary Ann - som havde bedt ham slå lyren igen. Jeg tror, det var mindet om Clara. Det er hendes magiske tunge, han tænker på. Men den unge lidenskabelige kærlighedsdrøm vil ikke mere gløde i et udslidt bryst, og den rene strøm vil ikke mere flyde fra det svulmende kildevæld. Claras magiske røst vil ikke mere lokke lyrens kækkeste toner frem. Hun er tabt.

Den betagelse af hende, som han måtte konvertere til en konventionel forlovelse med en sød og uskyldig pige, var det umuligt for ham at ryste af sig. Den gav ham et frygteligt samvittighedsnag over for den noble Mary Ann, og hans sjal og krop blev undergravet derved. Hver gang nogen taler om hans magerhed og udtærethed, fristes han til at ønske sig forløst fra livet (står der i brevet).

Stillingen er den samme i 1836. 14. maj bebrejder FB sin søn, at han ikke skriver en linie til Mary Ann. I maj og juni ved hun ikke, hvor han er. En kusine til ham skriver til sin mor, at det er skammeligt af ham ikke at lade sin mor høre et ord. Hun skriver til Cambridge, men hans venner $\operatorname{der}^{4}$ returnerer de breve, der kommer til ham, til London. Kusinen skriver: "I am sadly afraid he has some Chère Amie - many people suspect as much from his conduct. It would be far best to marry Miss Smith directly «. Beskyldningen mod Alex var uden tvivl uretfærdig. Det var en tabt veninde, der drev ham rundt.

Den samme velynder, der skaffede ham hans første embede, sørgede i december for, at han fik et nyt, ved Ely Chapel, Holborn, i den centrale del af London. Det var en berømt gammel bygning, men frygtelig forfalden og ukendt af folk omkring den. Kirken var kold og klam, og ved juletid fik han influenza ved at holde gudstjeneste der. Under sin sygdom frabad han sig ethvert 
besøg og han døde 17.1.1837. Mary Ann tog sig trofast af hans ulykkelige mor, der døde tre år efter.

Efter hans død skrev en kusine af ham til hans mor: "None loved him more than I - his sweet and guileless temper, "in wit a man - simplicity a child " - his brillant talents - high powers of mind - noble intellect - his bright and varied and original conversation. All these - made it my greatest delight and refreshment to listen while he spoke". (s. 912).

Jeg har fortalt om Alex for at fortælle om Clara Bolton. Det siger noget om hende, at en så ædel sjæl blev så dybt betaget af hende. Også digteren Grundtvig blev betaget af hende og grebet af hendes "magiske tunge" og af de horisonter, den åbnede for ham. Men mødet med hende førte for Alex til, at den rene strøm ikke mere flød fra sin kilde. Modsat Grundtvig. Han siger selv om den inspiration, han modtog:

Claras Aande aabned Munden, Klippen revned, Strømmen randt ...

1. Forøvrigt brugte han også vendingen, da han første gang skulle have sin kommende kone Mary Anne Wyndham Lewis til bords! "”O anything rather than that insufferable woman. But Allah is great", and putting his thumbs in the armholes of his waistcoat, a favorable attitude of his, he walked up to offer her his arm " (Bradford s. 51).

2. Af brevene til Disraeli fremgår det gang på gang, at hun også i denne periode er syg. "I really was monstrous ill, quite unable to sit up" (1. brev). "I can write but a few lines today I am so ill" (4. brev). "I have been very ill and am likely to be bled tonight" - med tilføjelsen i efterskriften: "This looks like the writing of a housemaid. I am really ill." (5. brev).

3. En bekendt af mig, Dr. Michael Hebbert, London, har fornylig i nogle arkiver konstateret, at Verbecke var "merchant" (uldopkøber i Sydengland og eksportør), og at han kun boede få år i Bread Street, hvor han kun findes i 1804 og 1807. Clara fik en broder i 1806. Familien omtales ikke i de kendte breve.

4. En af dem var William Whewell, Trinity College, som blev Grundtvigs ven i 1831 . 